\title{
POMIĘDZY SKŁADNIĄ A LEKSYKĄ - PROBLEMY PROCEDURALNE
}

Słowa klucze: jednostka leksykalna, współczesny język polski, nietypowa konstrukcja składniowa Keywords: lexical unit, modern Polish, atypical syntactic construction

\section{Wprowadzenie}

Nadawca komunikatu w trakcie budowania wypowiedzi wykonuje zasadniczo dwie operacje. Pierwsza polega na pobraniu z zasobu leksykalnego określonych wyrażeń, druga natomiast sprowadza się do takiego ich uporządkowania, aby powstała poprawna struktura. Obie czynności są w gruncie rzeczy wykonywane przez użytkownika automatycznie w tym sensie, że nie zadaje on sobie pytania, które ciągi słów zostały zaczerpnięte w całości ze słownika, a które są wynikiem operacji konkatenacyjnych. Odmiennie do problemu struktur tekstowych podchodzi badacz języka. Za pomocą testów lingwistycznych dąży on do oddzielenia jednostek leksykalnych - jednoi wielosegmentowych - od konstrukcji. Decyzja w tej materii nie należy jednak do łatwych i zależy bezpośrednio od przyjętego zestawu cech służących identyfikacji elementów słownikowych. Ten fakt sprawia, że we współczesnej polszczyźnie można wskazać wyrażenia, które lokują się na granicy dwóch domen badawczych - leksykologii i składni - a językoznawcy nie są zgodni co do ich statusu.

Problem odróżniania jednostek leksykalnych od złożonych struktur składniowych stanowił przedmiot licznych dyskusji, prowadzonych de facto $\mathrm{z}$ różnych punktów widzenia. Można wśród takich rozważań wskazać prace poruszające zasadnicze 
kwestie metodologiczne (zob. Bogusławski 1976, 1987a, 1987b, 1996; Lewicki 1983; Lewicki, Pajdzińska, Rejakowa 1987; Fillmore, Kay, O’Connor 1988; Willis 2007; Węgrzynek, Przybylska, Żmigrodzki 2012 i in.), jak również publikacje podejmujące szczegółowe kwestie analityczne (zob. Jędrzejko 1992; Żmigrodzki 2000; Zaron 2002; Kapotev 2008b; Przybylska 2009; Dobaczewski 2011; Rosalska 2011 i in.). Nie zmienia to faktu, że istnieją wyrażenia językowe, które wymykają się wypracowanym procedurom kwalifikacyjnym. $Z$ tego też powodu zasadniczym celem prowadzonych rozważań jest próba zastosowania do niewielkiego zbioru struktur o niejasnym statusie gramatycznym znanych definicji jednostek leksykalnych. Jednocześnie - co warto podkreślić - nie chodzi przy tym o doprecyzowanie samych definicji, co raczej wskazanie ich nieskuteczności w procedurach delimitacji tzw. frazemów składniowych. $\mathrm{W}$ założeniu tekst ten ma stanowić więc przyczynek do wypracowania procedur identyfikacji i analizy takiego zbioru wyrażeń.

Opis wyrażeń zaliczanych intuicyjnie do wskazanego zbioru, np. czego on nie robit czy rozebrać na czynniki pierwsze, nie był do tej pory szerzej prowadzony, a same obiekty notowano głównie w pracach poświęconych ekscerpcji materiału słownikowego (zob. Bogusławski, Garnysz-Kozłowska 1979; Bogusławski, Wawrzyńczyk 1993; Bogusławski, Danielewiczowa 2005). Uwagi na ich temat można znaleźć w opracowaniach związanych z koncepcją gramatyki komunikacyjnej (zob. Awdiejew 2001; Laskowska 2001), frazematyki (Chlebda 1991, 2001, 2010; Kozioł-Chrzanowska 2012) czy też w opisie struktur metatekstowych (zob. Ożóg 1990; Winiarska 2001). Charakterystyka takich wyrażeń cieszy się również popularnością w językoznawstwie rosyjskim (zob. Mielczuk 1995; Jomdin 2006; Apresjan 2007; Jordańska, Mielczuk 2007; Kapotev 2008a i in.). Warto także dodać, że analizowane zjawisko wiąże się do pewnego stopnia z problemem specyficznych struktur składniowych - konstrukcji werbo-nominalnych (zob. Żmigrodzki 200o).

Omawiane tu wyrażenia $z$ uwagi na swój niejednoznaczny status mogą być w równym stopniu uznawane za konstrukcje, jak i jednostki leksykalne. Przyczyną takiego stanu rzeczy jest m.in. sformułowany przez A. Bogusławskiego (1989) postulat, zgodnie z którym o odrębności leksykalnej decydują m.in. różnego typu anomalie formalne czy semantyczne, por.

(1) Wiem, co mówię.

(2) Jan wyjechał, co mówię, uciekł.

Jest rzeczą znamienną, że lokowanie analizowanych tu wyrażeń na przecięciu dwóch obszarów badawczych zmusza do ustalenia cech demarkacyjnych omawianej klasy, na co de facto zwracają uwagę autorzy Sond..., twierdząc, że „trzeba zachować należytą czujność, by nie pomylić [jednostek leksykalnych - AM] z pewnymi, uzualnymi, co prawda, ale jednak połączeniami” (Bogusławski, Danielewiczowa 2005: 12). Wydaje się więc, że nie da się wielu ciągów (np. mówiąc w największym skrócie) uznać za 
niepodzielne, choć użytkownicy korzystają z nich, jak z gotowego zbioru ${ }^{1}$. Ich cechą jest bowiem związek formalny (a często i semantyczny) $z$ jednostkami prostszymi. $\mathrm{Z}$ tego też powodu przyjmuje się tutaj, że bezpośrednim celem prowadzonych rozważań jest próba zdania sprawy $\mathrm{z}$ wątpliwości powstających przy identyfikacji i jednoznacznej ocenie wskazanych struktur ${ }^{2}$.

\section{Definicja jednostki leksykalnej}

Postawiony problem badawczy - ustalenie trudności proceduralnych dotyczących interpretacji struktur typu $w$ kimś jest ileśczegoś, ktoś będzie mi - zmusza do analizy cech dystynktywnych takich wyrażeń. Prowadzone rozważania będą wobec tego opierały się na próbie odniesienia do nich znanych definicji pojęcia jednostki leksykalnej.

Punktem wyjścia opisu jednostki słownikowej jest ustalenie jej kształtu. Zdaniem Macieja Grochowskiego (1982: 28) obiektem takim jest

[...] ciąg elementów diakrytycznych mający znaczenie globalne, czyli ciąg niepodzielny semantycznie na takie podciągi znaczące, które byłyby elementami klas substytucyjnych niezamkniętych.

Jak widać, podstawą wyróżniania są tu cechy semantyczne, a dokładniej brak możliwości podziału znaczenia globalnego na znaczenia cząstkowe. Warto dodać, że rozróżnienie klasy zamkniętej i niezamkniętej sprowadza się do przypisywania wyrażeniom charakterystyki ogólnej. Częścią jednostki są też miejsca walencyjne, por. ktoś ODZIEDZICZYŁ coś PO kimś czy ktoś PLUJE SOBIE W BRODĘ, ŻE $v_{\text {praet }}$.

Tak sformułowana definicja była później doprecyzowywana. Wprowadza się do niej m.in. pojęcie relacji składniowej, uznając, że w sytuacji, gdy „ciągi $a$ i $b$ nie reprezentują klas niezamkniętych $F$ i $G$ i jeżeli nie istnieje reguła $R$ [pozwalająca na łączenie elementów klasy $F$ z elementami klasy $G-\mathrm{AM}$ ], a mimo to ciągi współwystępują ze sobą, to znaczy, że stanowią one jeden ciąg c" (Grochowski 1987: 15). Jak można

1 W literaturze przedmiotu zwraca się uwagę na zróżnicowanie wyrażeń o niepewnym statusie. Ciągi takie mogą składać się: (1) z elementów niewymiennych (por. nie ma co); (2) z elementów, w których wymianie podlegają: (a) formy jednego leksemu, por. wiesz (wiecie) co; jak mogłeś (mogliście, możesz); (b) leksemy o różnej modyfikacji semantycznej, por. proszę pani (pana, państwa), lub deiktycznej, por. niech ci (mu, jej) będzie; (c) leksemy synonimiczne, por. nie ma sprawy (problemu, kwestii) bądź też (d) struktury różnią się liczbą segmentów, por. powiem jedno \| tylko jedno, zob. Laskowska 2001: 203-204.

2 Wywołany tytułem problem dotyczy w gruncie rzeczy możliwych przekształceń pewnych struktur słownych. Zjawisko takie może być wyjaśniane za pomocą różnych narzędzi opisu. Można m.in. dążyć do odróżniania jednostek leksykalnych o charakterze systemowym (względnie stałych) oraz jednostek funkcjonalnych, dopuszczających różne przekształcenia. W opracowaniu tym wybiera się jednak model konkurencyjny, a mianowicie podejmuje się próbę przypisania ciągom wątpliwym statusu jednostki języka, a w wypadku niejednoznacznego wyniku testu proponuje się wyróżnienie klasy bytów pośrednich. 
sądzić, jednym z kryteriów odróżniania jednostek leksykalnych od konstrukcji czyni się w takiej definicji możliwość zdefiniowania reguły pozwalającej na łączenie elementów dwóch klas.

Na operacyjny charakter definicji zwracają uwagę Adam Bednarek i M. Grochowski (1993: 13-14). Autorzy odnoszą pojęcie jednostki do takiego ciągu elementów diakrytycznych, któremu przysługują następujące właściwości:

Po pierwsze: dany ciąg (z przerwami lub bez), np. A, jest rozłączny z dowolnym elementem, który może wystąpić w pozycji Y lub Z w kontekście YAZ. Rozłączność rozumie się tu w ten sposób, iż znaczenie ciągu $A$ w kontekście $\mathrm{Y}_{1} \mathrm{AZ}_{1}$ nie jest różne od znaczenia ciągu A w kontekście $Y_{n} A Z_{n}$ (pozycje syntaktyczne $Y_{1}, Y_{2}, Y_{3}, \ldots, Y_{n}$ muszą być identyczne; to samo dotyczy $Z_{1}, Z_{2}, Z_{3}, \ldots, Z_{n}$ ).

Na tym etapie podstawą rozstrzygnięć jest stwierdzenie równo- lub różnoznaczności jednostek, nie zaś przypisanie im określonego znaczenia ${ }^{3}$. Po drugie,

[...] wszystkie wyrażenia mogące zajmować pozycje Y i Z muszą być elementami klas niezamkniętych. Klasa niezamknięta jest to zbiór elementów, któremu można przypisać charakterystykę ogólną (np. klasa imion, nazwy płynów). Klasę zamkniętą natomiast można scharakteryzować tylko przez wyliczenie jej elementów. [...] Po trzecie: żadna część A nie spełnia warunków nałożonych powyżej na A (Bednarek, Grochowski 1993: 14) ${ }^{4}$.

Jak widać, definicje jednostki leksykalnej zawierają komponenty formalne i semantyczne, co skłania do rozważenia obu tych aspektów ${ }^{5}$.

\subsection{Formalne cechy jednostek leksykalnych}

Zgodnie z przytoczonymi definicjami jednostkom leksykalnym można przypisać różne cechy formalne. Część z nich została uwzględniona explicite, część natomiast jest jedynie kojarzona $\mathrm{z}$ analizowanym pojęciem. Bezpośrednio $\mathrm{z}$ definicji wynika więc, że (a) nie określa się relacji składniowej między segmentami jednej jednostki (zob. Grochowski 1987: 15); (b) otwierane pozycje syntaktyczne stanowią część jednostki,

3 Jest to zgodne z tezą Bogusławskiego (1988: 215), że gramatyka winna rejestrować „odwieloznacznione kształty i wymagania dotyczące kształtów, a nie znaczeń [oraz - AM] przypisywać jednostkom miejsca walencyjne do wypełnienia obiektami klas niezamkniętych".

4 A. Bogusławski (1988: 171) wprowadza do opisu pojęcie kontrastywnego segmentu sylabicznego (KSS), uznając, że jest nim „element, który (a) jest rozłączny w sensie właściwym, (b) zawiera co najmniej jedną sylabę, (c) jest kontrastowalny niecytacyjnie”.

5 A. Bogusławski (1989) wymienia 12 cech przypisywanych zazwyczaj związkom frazeologicznym: odtwarzalność, powtarzalność segmentów w innych ciągach, wielowyrazowość graficzna, wielowyrazowość fonologiczna (akcentowa), nieciągłość, nieglobalna fleksyjność, asumaryczność znaczenia, obrazowość, ekspresywność, nietworzenie skończonego zdania, nietworzenie skończonego sądu logicznego, niepodzielność. Autor jednak konkluduje, że stosowanie pojedynczych właściwości może prowadzić do sądów sprzecznych, a poprawny rezultat przynosi jedynie kombinacja niektórych z nich. 
choć obiekty występujące w nich nie są już jej segmentami (zob. Bednarek, Grochowski 1993: 13); (c) granice jednostki leksykalnej mogą pokrywać się z granicami segmentu graficznego, obejmować kilka segmentów lub przebiegać wewnątrz takiego segmentu (zob. Grochowski 1982: 29); (d) segmenty danej jednostki nie podlegają wymianie, względnie wymienność taka jest ograniczona do listy elementów (zob. Bednarek, Grochowski 1993: 13-14).

Dodatkowo jednostkom skłonni jesteśmy przypisać pewne cechy pomimo faktu, że nie uwzględnia się ich w definicjach. I tak, (a) ich segmenty mają zwykle stałe uporządkowanie linearne ${ }^{6}$; (b) ich forma w ustalonym kontekście zewnętrznym nie podlega zmianie (uwzględniona substytucja dotyczy materiału leksykalnego) ${ }^{7}$; (c) liczba segmentów jest również stała ${ }^{8}$.

\subsubsection{Relacje składniowe wewnątrz jednostek leksykalnych}

Zgodnie z wcześniejszym stwierdzeniem między członami jednej jednostki leksykalnej nie identyfikuje się relacji składniowych. Rozstrzygnięcie takie - słuszne z teoretycznego punktu widzenia - może jednak budzić pewne kontrowersje. Faktem jest bowiem, że wyrażenia uznawane za jednostki w swojej strukturze nie odbiegają zasadniczo od typowych konstrukcji'. Jeżeli więc uznamy, że kluczem do ich wyróżniania jest relacja składniowa między członami, to jak rozstrzygnąć, że powiązanie między komponentami jednym i słowem w zdaniu (3) jest ustalane zgodnie z określoną regułą, a w (4) - nie, por.

(3) Skomentował wszystko jednym słowem.

(4) Jednym słowem to koniec.

Jeżeli dodatkowo uzmysłowimy sobie fakt, że strukturom wielosegmentowym możemy przypisywać zarówno składnię zewnętrzną, jak i wewnętrzną (zob. Lewicki 1983), to stosowanie procedury określania relacji syntaktycznej do identyfikacji jednostek leksykalnych należy uznać za zawodne. Wydaje się wobec tego, że analizowana tu właściwość nie powinna stanowić argumentu ani za rozłącznością określonych członów, ani przeciw takiej tezie. Pośrednio z tym problemem wiąże się kwestia stabilności form. Zgodnie z wcześniejszym stwierdzeniem jednostki słownikowe - umieszczone w niezmiennym

6 Informacja na ten temat pojawia się w Sondzie słownikowej III, kiedy autorzy przytaczają dopuszczalne warianty szyku, por. nieznany szerzej \{szerzej nieznany\}_(Bogusławski, Danielewiczowa 2005: 170).

7 Bogusławski i Danielewiczowa (2005) problem wymienności form ujmują w kategoriach wariancji jednostek, por. ktoś położył cośna swoim miejscu \{na swoje miejsce\} (s. 206) i traktują na równi $\mathrm{z}$ wymiennością segmentów, por. ktoś rozpocząt \{zacząt\} nowy etap w życiu ${ }^{o}$ (s. 172).

8 W Sondzie słownikowej III tego typu składniki uznaje się za fakultatywne komponenty jednostki,

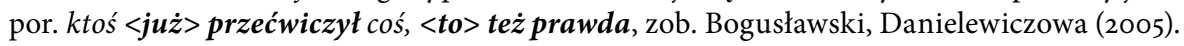

9 Zdaniem Marii Szupryczyńskiej (1996: 47) „[...] znaczna większość przykładów kwalifikowanych jako związki frazeologiczne może być uznana za typowe realizacje istniejących modeli składniowych”, a uznaje się je „za jednostki frazeologiczne ze względu na ich nieregularność semantyczną”. 
kontekście zewnętrznym - zachowują charakterystykę formalną swoich podciągów. $\mathrm{Z}$ tego powodu nie do końca wiadomo, jak interpretować przykłady: mówiąc łagodnie || najłagodniej czy bez komentarza \| komentarzy. Trudno w tym wypadku orzec, czy taka wymienność ma charakter systemowy, czy też powinna być uznana za substytucje o charakterze zamkniętym.

\subsubsection{Problem pozycji składniowej}

Niewątpliwie słuszną decyzją jest uznanie pozycji składniowych za część jednostki leksykalnej. Problem dotyczy jednak rozumienia tego pojęcia. W definicjach Grochowskiego $(1982,1987)$ odnosi się ono do wymaganych podrzędników (względnie współskładników - zgodnie z koncepcją Saloniego i Świdzińskiego 1998), por. ktoś odziedziczył coś po kimś. Odmiennie to zagadnienie interpretują Bogusławski i Wawrzyńczyk (1993) czy Bogusławski i Danielewiczowa (2005). Autorzy rozszerzają bowiem to pojęcie na wszystkie obiekty, z którymi jednostki mogą współwystępować, por.

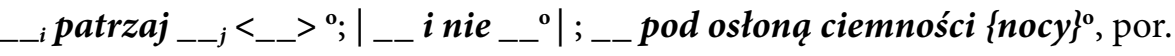

(5) Ten aktor, patrzaj Holubek, sprawiał na niej zawsze wielkie wrażenie.

(6) Chciał i nie chciał.

(7) Wymkniemy się pod osłoną ciemności.

Typ pozycji uwzględnianej przy jednostce jest niewątpliwie kwestią konwencji i założeń metodologicznych. Warto jednak przyjąć, że zajmują ją wyrażenia konieczne oraz że jest ona wyznaczona przez cechy formalno-semantyczne. Tym samym pozycji raczej nie będą zajmować ciągi o bliżej nieokreślonej charakterystyce (np.powiedzmy sobie nie nakłada wyraźnych ograniczeń formalnych i semantycznych na człony, z którymi się łączy).

Zasygnalizowane zagadnienie wiąże się jedynie pośrednio z podjętą tu tematyką, jest jednak konieczne do postawienia zasadniczego pytania o granicę jednostek i konstrukcji. Otóż, zgodnie z definicją segmenty jednostki leksykalnej mogą podlegać wymianie na inne elementy zamkniętego zbioru. Jeżeli tak, to należy rozważyć, kiedy substytucja taka dotyczy standardowego sposobu zapełniania pozycji składniowej, a kiedy wiąże się z wariantywną postacią segmentu ciągu niepodzielnego. Drugi problem z tym związany dotyczy typów elementów, o które można rozbudowywać jednostkę, por. Szupryczyńska 1996: 61-62.

Przykładem takich dylematów jest ciąg ktoś jest \{znajduje\} się pod presją cza$\boldsymbol{s u ^ { 0 }}$. Próba ustalenia zbioru przykładów, w których może on wystąpić, ukazuje kilka wątpliwości:

(8) Serwisant wciąż znajduje się pod presją czasu (NKJP) ${ }^{10}$.

10 Przykłady opatrzone skrótem NKJP pochodzą ze strony www.nkjp.pl 
(9) Prace odbywają się pod presją czasu (NKJP).

(10) Praca legislacyjna toczy się pod presją czasu (NKJP).

(11) Równocześnie zawodnik znajduje się pod presją otoczenia (NKJP).

(13) Żydostwo znajdowało się pod presją dwóch tysięcy lat europejskiej cywilizacji (NKJP).

Pierwsza z nich nie wymaga szerszego komentarza - element się jest częścią segmentu wymiany znajdować się, nie zaś jednostki. Po drugie, lista wyrażeń zastępujących segment jest wydaje się dłuższa, por. odbywa się, toczy się (pomija się tu sprawę zamkniętości zbioru oraz fakt łączenia się części segmentów wymiany z coś). Problemem jest też wymienność ciągu czasu (por. otoczenia, dwóch tysięcy lat, europejskiej cywilizacji). W tym wypadku jednak taka substytucja zmienia funkcje całości struktury, zwłaszcza przy paralokucji przyjętej przez autorów Sondy... - 'z pewnym prawdopodobieństwem podejmuje przyspieszoną decyzję, ponieważ okoliczności ograniczają czas, jaki $i$ ma do rozporządzenia'. Ostatnia sprawa dotyczy typu składnika występującego w pozycji ktoś. Prócz jednostek serwisant, zawodnik, żydostwo pojawiają się tu bowiem argumenty o innych cechach znaczeniowych (praca czy negocjacje). Zagadnienie to wymaga jednak analiz semantycznych, które na etapie identyfikacji kształtu jednostek są pomijane (por. Bogusławski 1988: 215). Bez względu jednak na ich wyniki funkcja ciągu jest pod presją czasu pozostaje ta sama, a wyrażenia z pozycji ktoś należą do klasy substytucyjnej niezamkniętej. Tym samym stałym elementem jednostki jest ciąg pod presją czasu. Wątpliwości dotyczą zaś wymienności segmentu jest oraz niemożliwości przypisania mu cech ogólnych ${ }^{11}$.

Osobną rzeczą jest obecność w strukturze jednostek fakultatywnych segmentów, co do których trudno orzec, czy należą do klas substytucyjnych zamkniętych, por.

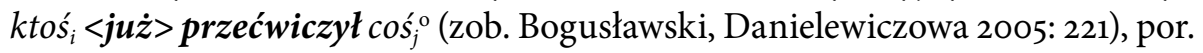

(14) Myśmy już te obniżki podatków przećwiczyli.

(15) Sam przećwiczył ich działanie.

Pomijając na razie sprawę szyku, warto zwrócić uwagę na niekonieczną część przytoczonego wyrażenia - $\langle j u \dot{z}>$. Zgodnie z definicją segmentami jednostki są elementy zbiorów zamkniętych, a tym samym albo nie podlegają one wymianie, albo też wymiana taka ogranicza się do listy wyrażeń. W analizowanym wypadku lista taka byłaby dwuelementowa - $\{j u \dot{z}, \varnothing\}$, co rodzi pytanie o wariant podstawowy. $Z$ drugiej strony, rozstrzygnięcia wymaga to, czy dołączanie takich wyrażeń jak chyba, tylko,

11 Problem liczby alternantów członów wymaganych był podnoszony przez językoznawców, por. Saloni, Świdziński 1998; Wiśniewski 2005; Moroz 2010; Gębka-Wolak 2011. 
prawdopodobnie, ale również niektórych przysłówków należy uznać za wariantywną postać jednostki, czy też dowód na jej niezleksykalizowany charakter, por.

(16) Napisał powieść śmiałą - że tak powiem - obyczajowo (NKJP).

(17) Stanisław Kania był na urlopie, że tak powiem kolokwialnie, „na pół gwizdka” (NKJP).

Wymienność segmentów jest bez wątpienia kluczowym problemem procedury ustalania kształtu jednostek i wymaga przy tym bardzo jasnego zdefiniowania zarówno założeń wyjściowych, jak i procedur kwalifikacyjnych.

\subsubsection{Problem uporządkowania linearnego segmentów jednostek leksykalnych}

Kolejna sprawa dotyczy linearyzacji segmentów jednostek leksykalnych. Należy jednak spojrzeć na nią z dwóch punktów widzenia. Po pierwsze, przekształcenia szyku mogą dotyczyć położenia składników zajmujących pozycje syntaktyczne otwarte przez części jednostki, co jednak nie wymaga szerszego komentarza, gdyż jest standardowym zachowaniem składników konstrukcji, por. ktoś $_{i}$ kieruje kimśs $_{j} /$ czymśs $_{k}$ z tylnego siedzenia ${ }^{\circ}$ :

(18) Pan kieruje nim $z$ tylnego siedzenia (NKJP).

(19) Nie będę nikim kierował z tylnego siedzenia (NKJP).

Inaczej jest w wypadku stałych segmentów jednostek. Definicje tego pojęcia nie zawierają informacji o dopuszczalności przekształceń szyku, co nasuwa przypuszczenie, że nie uwzględnia się ich w procedurach identyfikacyjnych. Być może powodem rezygnacji z tej właściwości jest brak kompleksowych badań w tym zakresie. Problem ten jest natomiast częściowo uwzględniony w Sondach... (1993, 2005), co można tłumaczyć materiałowym ich charakterem. Nie jest on jednak ujmowany w sposób jednolity. Wyrażenia zróżnicowane linearnie uznawane są za warianty jednostek, por. | przepraszam najmocniej / najmocniej przepraszam ${ }^{\circ}$ | bądź też sprawa ta jest pomijana, por. ktoś ${ }_{i}$ nadal komuśs $_{j}$ sprawe $e^{\text {: }}$

(20) Artur K. nadał przestępcom tę sprawę (NKJP).

(21) Wydział IV KWMO, który nam sprawę nadał (NKJP).

\subsection{Cechy znaczeniowe jednostek słownikowych}

W przytoczonych definicjach zwraca się przede wszystkim uwagę na semantyczne cechy jednostek leksykalnych. Warto wobec tego uzmysłowić sobie, że decydującą rolę 
odgrywa tu: (a) globalne znaczenie struktury (zob. Grochowski 1982: 28); (b) przynależność segmentów do klas substytucyjnych zamkniętych (zob. Grochowski 1982: 28); (c) nierozłączność segmentów oraz niezmienność ich znaczenia (Bogusławski 1988: 171; Bednarek, Grochowski 1993: 14). Jak się jednak okazuje, niepodzielność znaczeniowa nie zawsze jest oczywista. Dzieje się tak na przykład w sytuacji, gdy mamy do czynienia ze strukturą, w której występują element stały oraz zmienny. Nośnikiem znaczenia jest zwykle komponent stały, podczas gdy zmienny wprowadza dopuszczalne jego modyfikacje, por. gdzie on nie mieszkat.

Inny problem wiąże się z interpretacją pojęcia klasy substytucyjnej zamkniętej i niezamkniętej. Otóż w jego rozumieniu uwzględnia się dwa aspekty - możliwość przypisania znaczenia ogólnego oraz wymienność segmentów. Jeżeli tak jest, to poza oczywistymi przykładami, gdzie segmentom danej struktury nie da się przypisać cech ogólnych, por. biały kruk, istnieją wyrażenia, w których procedura taka jest do pewnego stopnia możliwa. Przykładem może być ciąg mówiąc w największym skrócie, któremu przypisuje się paralokucję 'podając w największym skrócie same najistotniejsze informacje’ (zob. Bogusławski, Danielewiczowa 2005: 158). Zauważmy, że komponent mówiąc nazywa czynność przekazywania informacji, a w największym skrócie precyzuje sposób wykonywania takiej czynności. Potwierdzeniem takiego stanu rzeczy są dopuszczalne (bo niezmieniające znaczenia danej struktury) przekształcenia:

(22) Ujmując sprawę w największym skrócie, jej istota sprowadzała się do... (NKJP).

(23) Idea, jeśli przedstawić ją w największym skrócie, polega na dopasowaniu [...] (NKJP).

(24) W największym skrócie rzecz ujmując, możemy rozmawiać o dwóch Polskach (NKJP).

(25) Taki był - w największym skrócie - plan powstania powszechnego (NKJP).

(26) Jej agenturalna edukacja była więc - mówiąc jednym słowem - nieukończona (NKJP).

Obserwacja powyższych przykładów prowadzi do przekonania o możliwości przypisania segmentom cech ogólnych, a tym samym istnieją podstawy do uznania ciągów mówiąc oraz w największym skrócie za rozłączne oraz - co również jest widoczne - za podlegające wymianie. Znamienne jest także to, że możliwa jest redukcja jednego $\mathrm{z}$ komponentów, w tym wypadku mówiąc, zob. w największym skrócie, co pogłębia jedynie wątpliwości dotyczące niepodzielności takiej struktury.

Jak można mniemać, przyczyną pokazanych kontrowersji jest krzyżowanie się dwóch odmiennych kryteriów - charakterystyki ogólnej oraz wymienności segmentów. Jest bowiem sprawą oczywistą, że jednostką języka będzie wyrażenie, w którym 
poszczególne segmenty nie podlegają wymianie. $\mathrm{W}$ takim wypadku nie da się im również przypisać ogólnego znaczenia, por._na $\boldsymbol{c z u j a}{ }^{\mathbf{0}}$ (zob. Bogusławski, Danielewiczowa 2005: 71). Inaczej jest w sytuacji, gdy jeden z segmentów może być wymieniony. Rodzi się wówczas wątpliwość, czy taka substytucja jest wynikiem ogólnej charakterystyki klasy, czy też dotyczy przypadkowych elementów, których nie da się znaczeniowo uogólnić, por. ktośs rozebrał \{roztożyt\} cośs na czynniki pierwsze ${ }^{\circ}$ (zob. Bogusławski, Danielewiczowa 2005: 73), por.

(27) Jeżeli rozbić na czynniki pierwsze zdanie „Polakom wstyd za Lecha Kaczyńskiego", jest ono zdaniem makabrycznym (NKJP).

(28) Kroplą drążącą skałę są dzieci rozkręcające pojazd na czynniki pierwsze (NKJP).

(29) Wygląda tak jak gdyby rozsypała się na czynniki pierwsze (NKJP).

(30) Komentatorzy już dawno problem wartości obrotów rozpracowali na czynniki pierwsze (NKJP).

Powyższe obserwacje prowadzą do wniosku, że krzyżowanie się dwóch odmiennych cech identyfikujących może prowadzić do pewnych trudności związanych z rozpoznawaniem kształtu jednostki słownikowej.

\section{Wnioski}

Przedmiotem obserwacji w niniejszym tekście były wyrażenia językowe, które z uwagi na swoje specyficzne właściwości semantyczne i syntaktyczne lokują się w przestrzeni pomiędzy leksyką a składnią. W ich wypadku bowiem stosowanie znanych definicji jednostek leksykalnych nie przynosi jednoznacznych rozstrzygnięć. Jak można przypuszczać, problem wyróżniania takich ciągów wynika do pewnego stopnia z zestawu cech przypisywanych w literaturze lingwistycznej obiektom słownikowym. Można bowiem uznać, że elementami takiego zbioru są jedynie wyrażenia o znaczeniu globalnym (znaczeniu, które nie podlega dystrybucji między ich segmenty) i składające się dodatkowo z podciągów należących do klas substytucyjnych zamkniętych (typowym tego wykładnikiem jest niepodleganie procedurom wymienności). Zgodnie z definicją jednostki takim podciągom nie da się również przypisać ogólnej charakterystyki semantycznej. Trudno jest natomiast na tej podstawie orzec, czy elementy słownika dopuszczają modyfikacje wewnętrznej struktury linearnej, czy też jej rozbudowę o fakultatywne segmenty. Jak można mniemać, kontrowersje dotyczące tych cech, jak również problemy z odróżnianiem podlegających wymianie segmentów jednostki od komponentów zajmujących przy niej pozycje syntaktyczne stanowią podstawową przyczynę wyróżniania struktur analizowanych w niniejszym tekście. Faktem jest natomiast to, że ustalenie 
statusu gramatycznego takich wyrażeń jest bez wątpienia pożądane, wymaga jednak wcześniejszego wypracowania analitycznych narzędzi badawczych.

\section{Literatura}

Apresjan J.D. [= Ю.Д. Апресян], 2007, Фраземы с наречиями молого количества мало ли. Компьютерная лингвистика и интеллектуальные технологии. Материалы междунароной конферениии Диалог 20о7, Москва, s. 16-22.

Awdiejew A., 2001, Problemy wyodrębniania i klasyfikacji frazemów, [w:] M. Balowski, W. Chlebda (red.), Frazeografia słowiańska. Księga pamiątkowa poświęcona prof. Halinie A. Lilicz, Opole, s. 195-201.

Bednarek A., Grochowski M., 1993, Zadania z semantyki językoznawczej, Toruń.

BogusŁawski A., 1976, O zasadach rejestracji jednostek języka, „Poradnik Językowy” nr 8, S. $356-364$.

BogusŁAWsKi A., 1987a, Obiekty leksykograficzne a jednostki języka, [w:] Z. Saloni (red.), Studia z polskiej leksykografii współczesnej II, Białystok, s. 13-34.

BogusŁawski A., 1987b, Jednostki języka a produkty językowe. Problem tzw. orzeczeń peryfrastycznych, [w:] M. Szymczak (red.) Z zagadnień słownictwa współczesnego języka polskiego, Wrocław, s. 17-30.

BogusŁaWski A., 1988, Preliminaria gramatyki operacyjnej, „Polonica” XIII, s. 163-223.

BogusŁawski A., 1989, Uwagi o pracy nad frazeologia, [w:] Z. Saloni (red.), Studia z polskiej leksykografii współczesnej III, Białystok, s. 13-30.

BogusŁawski A., 1996, Jeszcze o delimitacji bilateralnych wielkości językowych, [w:] E. Rzetelska-Feleszko (red.), Symbolae Slavisticae. Dedykowane Pani Profesor Hannie Popowskiej-Taborskiej, Warszawa, s. 47-56.

BogusŁawski A., Danielewiczowa M., 2005, Verba polona abscondita. Sonda słownikowa III, Warszawa.

BogusŁawski A., Garnysz-KozŁowska T., 1979, Addendum to Polish phraseology. Introductory issue, Edmonton.

BogusŁawski A., Wawrzyńczy J., 1993, Polszczyzna, jaka znamy. Nowa sonda słownikowa, Warszawa.

Chlebda W., 1991, Elementy frazematyki. Wprowadzenie do frazeologii nadawcy, Opole.

Chlebda W., 2001, Frazematyka, [w:] J. Bartmiński (red.), Współczesny język polski, Lublin, S. $335-342$.

Chlebda W., 2010, Nieautomatyczne drogi dochodzenia do reproduktów wielowyrazowych, [w:] W. Chlebda (red.), Na tropach reproduktów. W poszukiwaniu wielowyrazowych jednostek języka, Opole, s. 15-35.

DOBACZEWSKI A., 2011, O konstrukcjach typu SĄD SĄDEM, A SPRAWIEDLIWOŚĆ MUSI BYĆ PO NASZEJ STRONIE, „Poradnik Językowy” Z. 1, s. 35-42.

Fillmore Ch., Kay P., O'Connor M., 1988: Regularity and idiomaticity in grammatical constructions: the case of let alone, „Language” 63/3, s. 501-538.

GęBKA-WolaK M., 2011, Pozycje składniowe frazy bezokolicznikowej we współczesnym zdaniu polskim, Toruń. 
Grochowsкi M., 1982, Zarys leksykologii i leksykografii, Toruń.

Grochowsкi M., 1987, O kryteriach określania przedmiotu leksykologii, „Studia Linguistica Polono-Jugoslavica" 5, s. 151-155.

JęDRZEJKo E., 1992, Słownictwo tzw. analityczne w opisie leksykalnym (propozycja opisu i klasyfikacji), [w:] A. Markowski (red.), Opisać słowa, Warszawa, s. 50-61.

Jomdin L. [= Л.Л. Иомдин], 20о6, Многозначные синтаксические фраземь: между лексикой и синтаксисом, [w:] И.М. Кобозевой, Н.И. Лауфер, В.П. Селегея (red.), Трудь международной конференици по компьютерной лингвистике и интеллектуальным технологиям Диалог 20о6, Москва, s. 202-206.

Jordańska L.N., Mielczuk I. [= Л.Н. Йорданская, И.А. Мельчук], 20о7, Смысл и сочетаемость в словаре, Москва.

KAротіеW M. [= М.В. Копотев], 20о8а, Приниипь синтаксической идиоматизаиии, Хельсинки.

KAротіеw M. [= М.В. Копотев], 2008b, Гулять так гулять: between Grammar and Dictionary, [w:] М.В. Копотев, Приниипь синтаксической идиоматизации, Хельсинки, s. 89-10о.

KozIOŁ-Chrzanowska E., 2012, Frazemy, hece i reprodukty - w poszukiwaniu rozstrzygnięć terminologicznych do opisu wybranych konstrukcji wielowyrazowych, „Język Polski” XCII, Z. 4, s. 249-259.

Laskowska E., 2001, Miejsce frazemów w kontekście, [w:] M. Balowski, W. Chlebda (red.), Frazeografia słowiańska. Księga pamiątkowa poświęcona prof. Halinie A. Lilicz, Opole, s. 203-208.

LEwICKi A.M., 1983, Składnia związków frazeologicznych, „Biuletyn Polskiego Towarzystwa Językoznawczego" XL, s. 75-83.

Lewicki A.M., PAjDzińska A., Rejakowa B., 1987, Z zagadnień frazeologii. Problemy leksykograficzne, Warszawa.

Mielczuk, I.A., 1995, Phrasemes in Language and Phraseology in Linguistics, [w:] M. Everaert, E.J. van der Linden, A. Schenk, R. Schreuder (red.), Idioms: Structural and Psychological Perspectives, Hillsdale - New Jersey - Hove, 1995, s. 167-232.

Moroz A., 2010, Parenteza ze składnikiem czasownikowym we współczesnym języku polskim, Toruń.

OżóG K., 1990, Leksykon metatekstowy współczesnej polszczyzny mówionej, Kraków.

PRZYbYLSKa R., 2009, Dwie rodziny frazeologiczne z komponentem kapelusz, „LingVaria” IV, nr 2, s. 59-68.

RosALSKA 2011, 'Krok po kroku', 'krok za krokiem', 'krokw krok' - konstrukcje składniowe czy jednostki języka, „Linguistica Copernicana” nr 2(6), s. 149-162.

SAlONi Z., ŚWIDZIŃski M., 1998, Składnia współczesnego języka polskiego, Warszawa.

SzUPRYCZyŃsKa M, 1996, Pozycje składniowe frazy celownikowej $w$ zdaniu polskim, Toruń.

Węgrzynek K., Przybylska R., ŻMigrodzki P., 2012, Opis jednostek nieciaggtych $w$ Wielkim słowniku języka polskiego PAN, „Język Polski” z. 5, s. 353-367.

Willis D., 2007, Syntactic lexicalization as a new type of degrammaticalization, „Linguistics” 45, s. $271-310$.

WiNiARSKA J., 2001, Operatory metatekstowe w dialogu telewizyjnym, Kraków.

Wiśniewski M., 2005, Dystrybucyjne właściwości odprzymiotnikowych nazw cech we wspótczesnej polszczyźnie, Toruń. 
Zaron Z., 2002, Uwagi o wierzyć, że... Ile jednostek języka i jakie?, [w:] A. Engelking, R. Huszcza (red.), Pogranicza języków. Pogranicza kultur. Studia ofiarowane Elżbiecie Smułkowej, Warszawa, s. 56-62.

ŻMIGRODZKi P., 2000, Właściwości składniowe analitycznych konstrukcji werbo-nominalnych w języku polskim, Katowice.

\section{Between syntax and lexis. Procedural issues}

Summary

The paper discusses combinations of words which, due to their ambivalent grammatical status, are suspended on the borderline between lexis and syntax. The considerations aim to expose the ineffectiveness of the identification procedures of lexical units in the process of unambiguous interpretation of such objects as ktoś jest pod presją czasu 'someone is under time pressure' or rozebrać na czynniki pierwsze 'to thoroughly disassemble'. In the course of the discussion, a set of phrases selected from lexicographic works is first contrasted with the formal characteristics that are ascribed in the definitions to indivisible units (p. 2.1.), and then with semantic features (p. 2.2.). The essential goal of these operations is to demonstrate the practical difficulties that arise when one attempts to assign the analyzed strings to the appropriate set. 